Friern Hospital based on a multi-user Unix operating machine and it would be desirable to have compatibility with other Friern user districts. The system will provide ongoing evaluation of the developments within the community.

\section{REFERENCES}

'Wing, J. \& Hailey, A. M. (1972) Principles of evaluation. In Evaluating a Community Psychiatric Service. The Camberwell Register 1964-1971.

2JARMAN, B. (1983) Identification of underprivileged areas. British Medical Journal, 286, 1705-1708.

${ }^{3}$ SzMUKLER, G. I. et al (1981) Compulsory admissions in a London Borough: I \& II. Psychological Medicine, 11, 825-838.

${ }^{4}$ Ebringer, L. \& Christie-Brown, J. R. W. (1980) Social deprivation amongst short-stay patients. British Journal of Psychiatry, 136, 46-52.
${ }^{5}$ Feighner, J. P., Rubins, E., Guze, S., WoOdruff, R. A., WINOKUR, G. \& MUNOZ, R. (1972) Diagnostic criteria for use in psychiatric research. Archives of General Psychiatry, 26, 57-62.

${ }^{6}$ Krawiecka, M., Goldberg, D. \& VaughN, M. (1977) A standardised psychiatric assessment scale for rating chronic psychotic patients. Acta Psychiatrica Scandinavica, 55, 299-308.

${ }^{7}$ WYKes, T. \& STURT, E. (1986) The measurement of social behaviour in psychiatric patients: An assessment of the reliability and validity of the Social Behaviour Schedule. British Journal of Psychiatry, 148, 1-12.

${ }^{8}$ MCCreadie, R. G. (1982) The Nithsdale Schizophrenia Survey: I. Psychiatric and social handicaps. British Journal of Psychiatry, 140, 582-586.

${ }^{9}$ TAylor, J. \& PANtelis, C. (1987) Developing a microprocessor based case register, Abstract of Proceedings of the Conference on Computers in Psychiatry and Psychology. Bulletin of the British Psychological Society, 40, 5-6.

\title{
Videotape Reviews
}

War Neurosis: Netley and Seale Hall 1917-18 (UK, black and white, 1917, 26 mins)

Although this film is silent it is well sub-titled and is one of the earliest examples of psychiatric clinical recording on film. It was professionally made and very well photographed for the period. After 70 years its condition is probably more presentable than some contemporary videotape recordings will be in 2025 .

It shows various tics, spasms, hysterical paralyses and abnormalities of gait in service personnel arising from the stress of war. One patient constantly responded to the word 'bomb' by diving under the bed. Responses to treatment, which largely consisted of suggestion and 're-education', are shown, one case of monoplegia being 'cured' in just 15 minutes! Aspects of occupational therapy, including farm work, are illustrated and the film ends with a battle sequence acted and produced by the patients themselves - one of the earliest examples of psychodrama.

This unique archival material gives a valuable perspective on the evolution of psychiatry in the 20th century. The early concept of 'shell shock' becomes more understandable and there are illuminating glimpses of hospital beds, contemporary clothing and the discipline of the period. This film is one of many of psychiatric interest in the British National Film Archive.

Production: Pathé Frères. Format: VHS. Distribution: Available through the College. (Jane Boyce)

T. L. Pilkington University of Leeds
Neuropsychiatry 1943 (UK, black and white, 1943, 21 mins)

This film was made in the war-time documentary style and shows the treatment of neuroses in an EMS hospital. Although mainly for service personnel, civilians and children were also accepted.

The admission procedure is first shown, followed by medical examinations and extensive psychological testing, upon which there is considerable emphasis. The commentary is illuminating: "The psychologists co-operate closely with the psychiatrists", and "The social workers are there to assist the doctors". The traditional model persists, to the extent that the Medical Superintendent (casually smoking a cigarette) sees each patient and then allocates an appropriate doctor or therapist.

Physical methods of treatment are shown in detailcontinuous narcosis, modified insulin, unmodified ECT, I.V. barbiturate relaxation-and the programme of "remedial training", including OT, art therapy and the weekly hospital dance, is illustrated.

It is difficult to identify the intended audience for this film; the assertive commentary suggests a general one, but the identifiable patients and demonstrations of, for example, ECT, would seem to exclude this, even in war-time. However, it offers an illuminating glimpse of the emphasis and priorities at the time, when psychiatry was on the verge of the post-war explosion in physical methods of treatment.

Production: Spectator Films for the British Council. Director: Basil Wright. Source: National Film Archive. Format: VHS. Distribution: Available through the College. (Jane Boyce)

T. L. Pilkington University of Leeds 